Faculty of Business

Faculty Publications

This is a post-print version of the following article:

Spiritual Myths of Consumption: Puritanism, Transcendentalism and the Consubstantiation of the American Consumer, Journal of Marketing Management

Roy Suddaby

2019

The final publication is available at:

https://doi.org/10.1080/0267257X.2019.1585686

Citation for this paper:

Suddaby, R. (2019). Spiritual myths of consumption: Puritanism, transcendentalism and the consubstantiation of the American consumer. Journal of Marketing

Management, 35(5-6), 410-426. https://doi.org/10.1080/0267257X.2019.1585686 


\title{
Spiritual Myths of Consumption: Puritanism, Transcendentalism and the Consubstantiation of the American Consumer
}

\author{
Roy Suddaby \\ Peter B. Gustavson School of Business \\ University of Victoria \\ Canada \\ $\&$ \\ University of Liverpool Management School \\ University of Liverpool \\ United Kingdom
}

Draft Manuscript in Preparation for the Journal of Marketing Management 


\begin{abstract}
Contemporary consumer trends in America are profoundly influenced by the enduring religious values of Puritanism and the more secular spiritual values of Transcendentalism. Both belief systems have deeply penetrated American collective memory. While they share common historical roots, the tensions that emerge from their differences describe a typology of three enduring collective myths of American culture - the Myth of the American Dream, the Myth of the American Adam and the Myth of American Exceptionalism. These myths, in turn, define three contemporary consumer movements - Voluntary Simplicity, Transformational Consumption and Radical Consumption.
\end{abstract}

Keywords: spirituality, religion, consumption, collective memory, myths 


\section{Introduction}

Over one hundred years ago German sociologist Max Weber observed that capitalism was based on Protestant values of frugality, hard work and predestination. Weber termed this magic combination of values the spirit of capitalism because, somewhat ironically, the accumulation of worldly wealth appears to be premised on one's commitment to spiritual values. The spirit of capitalism, Weber argued, was perfected in the ethic of Puritanism in the New World.

If spirituality can help us understand how and why wealth is accumulated, it can also help us understand how and why wealth is spent. Like the accumulation of wealth, much of contemporary American consumption is based on foundational religious and spiritual values (Veblen, 1927; Hirschman, 1985; Luedicke, Thompson \& Giesler, 2009). In this essay, I extend this observation with the argument that we may gain a clearer understanding of how spirituality underpins consumption by distinguishing between formal religion, on one hand, and spirituality, on the other.

Viewed through a lens of historical consciousness (Suddaby, 2016), spirituality is the secular entropy of formal religion. In a span of two hundred fifty years, between the death of the Puritan founder of the Massachusetts Bay Colony John Winthrop in 1649 and the birth of Ralph Waldo Emerson in 1803, the stoic asceticism of the Puritan work ethic, that Weber so admired, evolved into the spiritual introspection of Transcendentalism.

The common tenets shared by these two cosmologies describe three enduring cultural myths that have come to define American institutions and culture - the myth of the American Dream, the myth of American Adam and the myth of American Exceptionalism. In combination, these two cosmologies and the cultural codes they create, provide the spiritual foundation for three 
highly influential contemporary cultural consumer movements - Simple Living, Transformational Consumption and Radical Consumption.

\section{Myth, Ideology and Consumption}

Much consumer behaviour is influenced by prevailing cultural codes - foundational cultural beliefs that, over time, become so historically embedded in societal institutions, ideologies and myths that they become taken-for-granted and disappear from critical reflection (Holt, 2004; Holt \& Cameron, 2010; Schroeder \& Morling, 2006). Current research has largely focused attention on consumer brands as the ultimate distillation of cultural codes. Brands provide a visible symbol, attached to a material objects or practices of consumption that reinforce cultural codes. Brands have become "vessels of meaning and sentiment that are valued in society" and which "work to organize collective identities, as expressions of the major social axes such as class, gender, and race within a particular national discourse and beyond" (Holt, 2006: 357). Brands, thus, make collective memory manifest as myth.

I add "religion" to Holt's list of major social axes. Despite modernist assumptions of the triumph of progressive rationality and scientific knowledge over such primitive belief systems as magic and religion, the re-emergence of religious fundamentalism since the late 1970s reinforces the observation that modern institutions cannot ever fully escape the sedimentary influence of religion (Suddaby, Ganzin \& Minkus, 2017).

The term "cultural strategy" has been coined to describe the process by which the ideologies of long-standing cultural codes become embedded in the commercial brands of iconic corporations. As Holt and Cameron (2010) ably demonstrate, the "Just Do It" mantra of Nike evokes the myth of American Exceptionalism, just as the brands of Jack Daniels and Marlboro 
draw from the rugged myth of American Individualism. Similarly, Luedicke, Thompson \& Giesler (2010) demonstrate how the General Motors automobile brand, the Hummer, has evoked a consumer morality play that pits Calvinist asceticism against rugged American Individualism.

While we have a clear understanding of the brand as the symbolic repository of cultural codes, we know much less about the historical and institutional processes through which the brands become suffused with meaning and social value. Although we have a growing understanding of the ways in which the cultural codes of branding inform social identity and collective memory (Muniz \& O’Guinn, 2001; Cova, Kozinets \& Shankar, 2012), we lack insight "on cultural processes that affect contemporary brands, including historical context" (Schroeder, 2009: 123, emphasis added).

The intent of this essay is to offer an illustrative example of the process by which historically embedded codes of religion and spirituality have been infused in contemporary myths of consumption. I point to the critical role of collective memory as the cornerstone of all myth, including myths of consumption. Collective memory, also termed cultural or social memory, is the fundamental system of texts, images, rituals and related material practices through which a social group uses the past to define its identity and purpose, and its core values and beliefs (Halbwachs, 1925; Assman, 1992). Collective memory is mobilized as a resource for social action - from creating the identity of nation-states (Anderson, 1991) to motivating social movements (Olick \& Robbins, 1998) - by the skilful use of language to reframe understandings of the past for uses in the present, a process termed rhetorical history (Suddaby, Foster \& Quinn-Trank, 2010).

Because religion is such a profound and defining element of the history of human experience, it is perhaps unsurprising that these myths originate in religious ideology. Following Weber's logic, however, it is also unsurprising that, over time, the enchanted myths of our 
collective religious experience become replaced with more rational and secularized myths of spirituality. My interest is in exploring the genealogical tension that arises from the process of erosion in religious myths and the emergence of myths of spirituality. As I argue in the balance of this essay, foundational myths never fully fade away. Rather, they are temporarily suppressed by the sediment of alternative replacement myths until new social conditions arise that allow them to re-emerge.

\section{Three core tenets of Puritans and Transcendentalists}

While one might argue that all myths are spiritual, religious doctrines offer the most impactful demonstration of how memory, myth and ideology interpenetrate each other. Capitalist ideology, as we know from Weber, is built on Puritan myths derived from the collective memory of the historical experience of the first colonists in the New World. To escape persecution in England, a great wave of Puritan's arrived in North America between 1620 and 1640 in a mass migration remembered as The Great Awakening (Heimart, 2006). One of the largest contingents was the Winthrop fleet of 1630 which consisted of eleven ships carrying over 700 colonists. Their leader was John Winthrop, a lawyer and soon-to-be governor of the Puritan Massachusetts Bay colony (Anderson, 1995). More significantly, Winthrop's evocative writings would come to define the core tenets of Puritanism in America.

Three core values defined the Puritans and distinguished them from other Protestant sects populating the American colonies (McLoughlin, 1978). Foremost was their asceticism. While all Protestant colonists rejected the conspicuous displays of wealth and power of English and European churches, the Puritans were acutely severe in their frugality and commitment to hard work. Second was their acceptance of the doctrine of predestination. The Puritans did not believe that hard work would grant them the grace of God or entry to heaven. God had already made that 
decision and the chosen people could only infer that decision by the clues that God provided as they suffered through life. Third was the Puritan commitment to the conversion narrative, public and personal confessions of sin and rebirth. Inherent in the conversion narrative is an assumption of the regenerative effect of faith.

The three tenets of asceticism, predestination and conversion served the Puritans well for over a century and a half. The decline of Puritanism is often attributed to the success of these principles (Emerson, 1977). The commitment to frugality and hard work made many Puritans successful and more interested in secular than celestial matters. Their commitment to predestination made some Puritans overzealous in policing membership with women often suffering the most from accusations of not being part of God's chosen people, most notably being decried as witches. By the early 1700s the influence and power of Puritanism as a formal religion in America was clearly on the wane.

The core doctrines of Puritan belief did not, however, disappear. While the formal institutions of the religion were fully eroded by the end of the eighteenth century, the core tenets of asceticism, predestination and conversion re-emerged in secular form during the Second Great Awakening, a revival of Protestantism that occurred in the early nineteenth century (Hankins, 2004). An emerging group of prominent theologians, many of whom were Unitarian ministers highly influenced by ideas of Enlightenment emerging from philosophers like Immanuel Kant and John Locke, began to articulate a more spiritual form of theology that transformed the old Puritan doctrines into a more secular articulation of naturalistic spirituality. This was the beginning of American Transcendentalism.

The core ideas of Transcendentalism emerged largely from the writing of Ralph Waldo Emerson, a graduate of Harvard's Divinity School, who borrowed from Kant the rejection of pure 
empiricism and the prominence of individual interpretation in understanding reality (Hankins, 2004). In his influential essay Nature Emerson began to articulate the foundation of American Transcendentalism - self-reliance, individualism, and idealism through nature. As we elaborate below, not only do these core principles of Transcendentalism derive directly from Puritan tenets of asceticism, predestination and conversion, they also form the foundation of three defining myths of American collective memory - the Myth of the American Dream, the Myth of American Adam and the Myth of American Exceptionalism. We summarize the relationship in Table 1

Insert Table 1 about here

\section{Asceticism and the Myth of the American Dream}

The enduring myth of the American Dream is that anything is achievable for anyone through hard work, frugality and dedication to one's calling. The ethos is best captured by Benjamin Franklin's well-known adage "early to bed and early to rise will make one healthy, wealthy and wise.” The American Dream artfully combines secular dreams of wealth and social mobility with Puritan ethics of hard work and frugality and Transcendental ideals of peace and wisdom through introspection and Self-Reliance.

The myth was best articulated by American writer and historian James Truslow Adams who is attributed with having coined the term in 1931. He defined the Dream as that:

"dream of a land in which life should be better and richer and fuller for everyone, with opportunity for each according to ability or achievement. It is a difficult dream for the European upper classes to interpret adequately, and too many of us ourselves have grown weary and mistrustful of it. It is not a dream of motor cars and high wages merely, but a dream of social order in which each man and each woman shall be able to attain to the fullest stature of which they are innately capable, and be recognized by others for what they are, regardless of the fortuitous circumstances of birth or position." 
While the reality of the American Dream is much debated (indeed, Adams himself acknowledges doubt in his definition), one cannot question the profound influence it has had in American public discourse.

The Dream is premised on America's collective memory of both Puritan values of asceticism and Transcendentalist principles of self-reliance. Puritans saw hard work and frugality as the path to spiritual salvation. Worldly success was the inevitable outcome of hard work and frugality, but it was also a sign that one stood in God's good grace. Weber's observation of middle class American life during his short visit to the United States in 1904 crystallized his conclusion that an ethical commitment to work, self-discipline and economic ambition was the obvious formula for capitalism. Work, for Puritans, was not simply a means to an end, rather it was part of God's calling. All work, according to the Calvinist philosopher Thomas Carlyle, is noble, even cotton spinning (Diddams, Whittington \& Divago, 2005).

Transcendentalists adopted a somewhat more mystical interpretation of both work and frugality. Hard work was seen not as a path to gaining God's good grace, but rather was a path to Self-Reliance. Work was the introspective work of interrogating the self and the goal was more achieving autonomy and independence than material wealth. An extreme version of this form of work is demonstrated by Henry David Thoreau's (1854) work of withdrawing from the world and a living a life of reflective thought in nature, as described in Walden. Frugality, for Transcendentalists, meant efficiency and parsimony, both in act and thought. Living a simple life was the ultimate expression of frugality as exemplified, again by Thoreau's famous quote "Our life is frittered away by detail ... simplify, simplify."

As I discuss below, it is the intersection of the somewhat orthogonal demands embedded in the puritan morality of hard work and frugality - asceticism, on the one hand, and the 
Transcendentalist spirituality of self-reliance, on the other, that has come to define the prominent consumer movement of Voluntary Simplicity.

\section{The Conversion Narrative and the Myth of American Adam}

The myth of American Adam is a myth of rebirth and regeneration. According to literary critic R.W.B. Lewis in his book The American Adam the myth is premised on the Biblical figure of Adam as the first man, an individual completely unburdened by his past. According to Lewis, early generations of Americans, most particularly the Puritans, became fascinated by the idea that their presence in the New World gave them the opportunity to jettison their history and reinvent themselves, both individually and as a society:

[T] he American myth saw life and history as just beginning. It described the world as starting up again under fresh initiative, in a divinely granted second chance for the human race, after the first chance had been so disastrously fumbled in the darkening Old World. It introduced a new kind of hero, . . an individual emancipated from history, happily bereft of ancestry, untouched and undefiled by the usual inheritances of family and race; an individual standing alone, self-reliant and self-propelling, ready to confront whatever awaited him with the aid of his own unique and inherent resources (Lewis, 1955: 5).

The myth permeates American literature, from Theodore Dreiser's main character Clyde in An American Tragedy, to Don Draper, the central character in the popular television series Mad Men or Patricia Highsmith's sociopathic hero Tom Ripley - individuals who are desperate to rise above their class and abandon their identity in order to achieve material and spiritual success. The myth also permeates American political discourse, from Thomas Paine's description of America as "the beginning of a new world" to Jefferson's belief that the "tree of liberty must be refreshed", by violence if necessary. Most critically, the myth of regeneration defines much of the popular business press - from Dale Carnegie to Stephen Covey, in emerging New Age markets devoted to self-help, personal transformation and a constant search for the "new, new thing" (Lewis, 1999). The myth of American Adam, thus, has spawned many billion-dollar industries. 
The myth is built on the Puritan idea of the conversion narrative, a ritual by which individuals achieve catharsis through public testimony about their religious experince. The testimony was offered in support of the understanding that an individual was on his way to sainthood - i.e. that he was in God's good grace and one of the chosen people. At its core, the conversion narrative was a story of regeneration or rebirth (Slotkin, 2000). The testimony offered a clear declension between an individual's past and future and was typically accompanied by material changes in demeanor, behavior and financial commitments to the church or the community.

The Puritan conversion narrative is perhaps best illustrated by John Bunyan's classic novel Pilgrim's Progress in which the main character, Christian, abandons friends and family to engage in a long and tortuous journey to the Celestial City. The novel effectively captures the core tenets of Puritan conversion - a form of spiritual and material conversion in which the hero finds God and wealth in a tortuous journey through the wilderness. Bunyan's conversion narrative, as Schwarzkopf (2012: 286) notes, was understood by Max Weber as akin to a market transaction with God:

"The English Baptist preacher Bunyan, whose life-journey turned him from an itinerant trader haunted by inner voices that told him to 'sell-Christ' into the author of the Pilgrim 's Progress (1678/1884), embodied this connection between the Self-enabling account-book and the market-oriented mindset. According to Weber, Bunyan's vision of the relationship of the sinner to God was that of the customer to the shopkeeper: "one who has once got into debt may well, by the product of his virtuous acts, succeed in paying off the accumulated interest, but never the principal (Weber, 1930/1905: 124)"

The Puritan act of conversion, thus, was itself an expression of market capitalism.

For Transcendentalists, conversion was a more spiritual and introspective event, premised upon Transcendental valorization of individuality. The moment of conversion was not the revelation that one was in God's good grace, but rather an awareness that God is within oneself. 
Emerson described men and women as "gods in ruins" and the moment of conversion was not on the basis of miracles but rather a discovery of God's expression in the higher ideals of human nature and in one's communion with Nature. Man need not wait for a sign from God. By selfreliant introspection and reflection, the internal conversation with the self was an opportunity to speak directly and individually to God.

As I demonstrate below, the Myth of American Adam, in its Puritan forms of regeneration through violence and in its Transcendent forms of regeneration by overcoming our animalistic tendencies has become manifest in the well-established social movement of Transformational Consumption.

\section{Predestination and the Myth of American Exceptionalism}

The myth of American Exceptionalism is the idea that Americans, both as individuals and as a nation state occupy a unique place in the world. It is premised on the notion that "Americans have a distinct and special destiny different from that of other nations". A prior term, Manifest Destiny, offered an earlier version of the myth. The term was first used by US Senator John O'Sullivan to justify the annexation of Texas. It was, O'Sullivan said "our manifest destiny to overspread the continent allotted by Providence for the free development of our yearly multiplying millions." The myth of America's Manifest Destiny, according to Slotkin, was an extension of the Myth of the Frontier and the assumption of American ascendance and superiority.

American exceptionalism is a modern extension of Puritan notions of pre-destination. As cultural historian Sacvan Bercovitch (1975) notes in The Puritan Origins of the American Self, Puritanism was different in its version of America as "the promised land", a form of heaven on earth. While other colonies still identified as Europeans and deferentially attached the name of their colonies to their European collective memory (i.e. New Amsterdam, New Sweden, New 
England), the Puritans coined new localized names for their colonies. Puritans conceived of the American Paradise as the fulfillment of the biblical prophecy of heaven on earth. It is no accident, Bercovitch notes, that Cotton Mather's biography of John Winthrop is titled "Nehemias Americanus" as this is a direct reference to Nehemiah, the saint who led the Israelites back from Babylon to the promised land. Nor is it an accident that the rhetoric that John Winthrop used to describe his colony as God's chosen people - referring to their presence in the New World as a celestial "city upon a hill" a phrase borrowed from the book of Matthew - has been repeated by Presidential candidates from Kennedy to Reagan to Obama in an effort to reaffirm American Exceptionalism.

For Transcendentalists, predestination was expressed in this life, not the afterlife, and was most manifest in the intricate beauty and idealism of Nature. God's grace was expressed not in acts of supernatural power but rather in the complex variety of the natural world. As Whitman (1973: 59) observed, "A mouse is a miracle enough to stagger sextillions of infidels". Because of their somewhat secular emphasis on the individual, Transcendentalists saw American Exceptionalism in the perfectability of the individual rather than the community. However, the perfect individual was most likely to be of New England Protestant stock as this quote from Ralph Waldo Emerson's brother Edward, who was sent to live in the southern US for health reasons, shows: ""Men do not strive here as in New England after the perfect man. It is present pastime or gainful industry or chance which they follow as their stars" (Mayo-Santana, 2014: 85). For Ralph Waldo Emerson, American Exceptionalism was expressed in the need to develop an indigenous intellectual base for American philosophy and scholarship. In his address to ... titled "The American Scholar", Emerson argues that American nature and ideology must become the model for an ideal American society (Madsen, 1998), and, by implication, for all other societies. 
As I argue below it is the intersection between Puritan notions of American Exceptionalism, premised on the ethic of a chosen people, and Transcendental notions of the perfectability of the individual through reflection and Nature, that creates the ideological conditions for the Radical Consumer movement.

\section{A Typology of Spiritual Consumption}

Not only do the formal religious tenets of Puritanism and the more secular spirituality of Transcendentalism underpin three enduring myths of American cultural identity, they also influence three dominant social consumer movement of contemporary American capitalism. The core tenets of Puritan religion (asceticism, conversion and predestination) intersect with the core tenets of Transcendentalism (self-reliance, individualism and idealism through nature) in each of the three mythological narratives that define American's cultural memory. In specific combinations, however, individual tenets of Puritanism and Transcendentalism coalesce to define three distinct categories of contemporary consumption - Voluntary Simplicity, Radical Consumption and Transformational Consumption. Because they are so deeply penetrated by core spiritual values, they can best be described as social movements of consumerism.

While each of these categories are well established in both the academic and practitioner literatures, their roots in the collective memory of American theology and spirituality are not. In the balance of this section I briefly elaborate those roots and offer illustrations of how three prominent consumer brands have effectively used those myths as the basis of their marketing campaigns. Figure 1 summarizes the argument by demonstrating how the core values of asceticism and self-reliance cohere in the myth of the American Dream to underpin the do-it-yourself movement that underpins Voluntary Simplicity. Similarly, the core values of conversion and individualism, which combine in the myth of American Adam, inform the movement to 
Transformational Consumption. Finally, the core values of predestination and idealism through nature, which define the myth of American Exceptionalism, characterize the social movement of Radical Consumption.

Insert Table 2 about here

\section{Voluntary Simplicity and a Return to the American Dream: IKEA}

Voluntary simplicity is a spiritually inspired social movement that rejects the celebration of materialism inherent in hedonic consumption and encourages individuals to slow down and embrace the simple life (Etzioni, 1999). The movement is articulated in a series of popular books such as Juliet Schor's The Overspent American: Upscaling, Downshifting, and the New Consumer, Duane Elgin's Voluntary Simplicity, Joe Dominguez and Vicki Robin's Your Money or Your Life or David Shi's The Simple Life: Plain Living and High Thinking in American Culture. It embraces a series of related social movements that focus on sustainable consumption such as The 100 Mile Diet, Slow Food, the film Simple Living and, in academia, The Slow Professor.

To be clear, the movement is not new. Charles Wagner, a French theologian, wrote The Simple Life in 1901. His book was highly influential at the time and earned him an invitation to the White House by Teddy Roosevelt. The ethos of simplicity was advocated by Ghandi, the Quakers and, more currently, Pope Francis. Nor it is overtly anti-consumption. Rather, it is a rejection of conspicuous consumption. The do-it-yourself renovation movement, IKEA and nofrills airlines, each of which are billion-dollar industries, openly embrace the rhetoric of simple living and are premised on positioning their products and services within Puritan values of frugality, hard work, self-reliance and the moral and spiritual satisfaction that is presumed to occur as a result. 
Indeed, simple living comprises such an important consumptive category that the prominent brand management consulting firm Siegel + Gale has constructed a Global Brand Simplicity Index. Now in its seventh year, the Index ranks brands on the degree to which global corporations embrace consumer values of simplicity - i.e. environmentally conscious packaging, value for money and simple but consistent retail outlets. In their promotional material, Siegel+Gale claim that 64 percent of consumers are willing to pay more for simpler experiences, 61 percent of consumers are more likely to recommend a brand because it's simple and that a stock portfolio of the simplest global brands outperforms the major indexes by 330 percent (Siegel \& Gale, 2018). While the claims have not been subject to independent empirical validation, the rhetorical claim is clear - simplicity sells.

Moreover, marketing strategies that link the historical Puritan ethic to the myth of the American Dream are prominent in promoting these brands. While there are several illustrative examples that could be used to demonstrate this practice, we focus here on a relatively recent advertisement used by the global furniture supplier IKEA. Although IKEA had a presence in the US market for three decades, it was struggling to overcome the perception that its products were designed exclusively for college students or young families just starting out in life. Working with Ogilvy \& Mather and based on an Economist Intelligence survey of two thousand American consumers, the company engaged in a campaign titled "We Can Help You Make It" that was clearly designed to connect traditional Puritan values of frugality and self-reliance to the lost myth of the American Dream (See Figure 1).

Insert Figure 1 about here 
The advertisement provocatively challenges the contemporary hedonic version of the American Dream as realized by the accumulation of material wealth and advocates a return to core Puritan spiritual values of simple living, frugality and success through meaningful relationships. As Robert Klara (2016: observes in Ad Week, Ikea has tapped into a shift in American values:

That shift, according to Ikea, means consumers are measuring the American dream less in terms of material accumulation - the suburban McMansion with a new SUV in the driveway - and more in terms of making the most of what they have, living life on their own terms, and focusing on creating memories instead of just accumulating more things.

The Voluntary Simplicity movement offers a clear rejection of the materialist self-interest

of the 1970s and 1980s, best captured by Milton Friedman's famous statement "the social responsibility of business is to increase profits" or the "Greed is Good" mantra of the Gordon Gecko character in the movie Wall Street. According to David Shi (2007), prominent historian of the Voluntary Simplicity movement, the primary values of the movement mirror Puritan values of ascetism and Transcendental values of self-reliance with their focus on conscientious consumption, thoughtful frugality and a commitment to responsible use of the earth's resources practices which Shi terms "enlightened consumption".

There is growing empirical evidence of the rise of "inconspicuous consumption", not only in established western economies but also in emerging markets. Eckhardt and colleagues (2015) demonstrate an emerging affinity amongst elite consumers for products that make their brand or logo so discreet as to be nearly invisible. Many luxury brands, including Louis Vuitton, Tom Ford and Michael Kors, have removed obvious branding from their products and seek somewhat obscure shelf placement in retail outlets in an effort to signal the elite nature of their brand, and their consumers, through discretion and understated design elements. Even the wealthy, it seems, are persuaded by appeals to Puritan and Transcendental values.

Transformational Consumption and the Myth of American Adam: Lululemon 
Transformational Consumption emphasizes the introspective self-discovery of Transcendentalism. It's secularized extension of Puritanism replaces devotion to God with devotion to self-discovery and personal growth. According to Tara-Nicholle Nelson, the bestselling author of The Transformational Consumer, this category of consumer seeks three types of personal change:

Transformational Consumers are a massive and growing group of people who see life as a never-edning series of projects to live healthier, wealthier, wiser lives. They spend a great deal of their time and money on the products, services, and content that can help them make these changes. They are early adopters...They are triathletes, Crossfitters and fitness walkers...If you have been vegan and Paleo, at different times in your life, you might be a Transformational Consumer...They are always studying a course in something, exploring a new certification or starting a business on the side...They experiment with frugality. They think a lot about designing their lives and course correcting the total picture of what they do with their work, their careers, and their time (Nelson, 2017: 3).

It is no accident that Nelson leans heavily on Benjamin Franklin's famous adage of "healthy, wealthy and wise" in defining the Transformational Consumer. Like many Transcendentalists Franklin "shared a common...non-sectarian religiosity, a native independence of theology" and assumptive optimism with Emerson and other Transcendentalists (Bier, 1972: 180).

Academic research on transformational consumption focuses on the bundling of "products, services, and experiences in ways that provide consumers with opportunities to alter who they are" (Kleine, Kleine \& Brunswick, 2009). Research, thus, demonstrates how brands can be used to construct personal identity (Schembri, Merilees \& Kristiansen, 2010) or to rediscover it (Gao, Wheeler \& Shiv, 2008). While prominent social critics are dismissive of the notion that spirituality or moral aims might be achieved through capitalist consumption (Baumann, 2007), the Transcendentalist notion that we can alter society through living "a good life" of consumption is inherent in the definition of transformational consumption offered by the, then, President of the Association for Consumer Research, Glen Mick who observed that research on transformational 
consumption holds the potential to address fundamental social problems with an aim to "respect, uphold and improve life" (2006: 2). The topics of research he identified, perhaps not coincidentally, addressed recognized human failings or sins of obesity, alcohol, gambling and violence.

Embedded in the Myth of the American Adam is the notion of social mobility - the idea that anyone, regardless of race or wealth, can achieve material and spiritual wealth. While research increasingly challenges the notion of social mobility, recent marketing research demonstrates that the myth of social mobility continues to be reinforced in American advertising. Analyzing a large sample of American print advertising from 1950 to 2015, Paulson \& O'Guinn (2017) determined that, just as most American's overestimate the size of the "middle class" so too is the middle class misrepresented in print advertising. The researchers found that the middle class in advertising is twice the size of the actual middle class. Moreover, they found that the content of advertising tends to reinforce the myth of social mobility by providing "instructions about how to appreciate certain products, making mobility seem possible" and by disproportionately using images of "upper-class celebrities rather than the hereditary rich." The authors conclude that advertising helps maintain the myth of individual transformation in American society, despite increasing evidence of its improbability.

Perhaps the best illustration of the transformational consumer is offered by the prominent clothing brand Lululemon. As can be seen from the text on their iconic product bag, Lululemon powerfully espouses the mythic ability of personal transformation (See Figure 2). The text segments artfully combine Puritan self-discipline ("sweat once a day") and exceptionalism ("mediocrity is as close to the bottom as it is to the top and will give you a lousy life") with the introspection of Transcendentalism ("your outlook on life is a direct reflection of how much you 
like yourself"). The text reinforces Transcendental expressions of the American Dream ("the pursuit of happiness is the source of all unhappiness" "friends are more important than money") and the need to constantly reinvent the self ("Have you woken up two days in a row uninspired? Change your life!").

Insert Figure 2 about here

Critics of the company have pointed to its cult-like obsession with personal transformation. In an interview Margaret Wheeler, senior Vice President of HR, confirms that

"In terms of core values and having the vision-and-goals, those things are really in our DNA. What we try to do is work on the self first. You'll see that with personal responsibility, with the opportunity to attend (personal development workshops at) Landmark as a choice, with setting a vision for all aspects of our life. That's actually the core of it."

Employees are required to re-examine personal goals at least twice a year. As part of their onboarding process, all employees are encouraged to engage in a three-day personal transformation workshop at Landmark, a popular human resources and personal development company used by Google, Apple and other iconic American corporations, in which participants are encouraged to "remove the constraints of the past" (McKnight, 2013). The rationalized capacity to surgically remove the burden of one's memory of the past is not only a core practice of modern spiritual cults, it is perhaps the ultimate expression of the myth of the American Adam.

The pervasiveness of the myth in American culture reaches its apex in the veneration of the recovery movement, which focuses attention less on the consumption of products and more on the consumption of moral vices - drugs, sex and alcohol - and the valorization of those who overcome them. In his book The Saloon and the Mission: Addiction, conversion and the politics of redemption in American culture, historian Eoin Cannon notes that sobriety and recovery 
narratives form the heart of modern American culture. Cannon argues that William James, the godfather of American psychology and the godson of Ralph Waldo Emerson, used narratives of recovery and redemption to demonstrate the regenerative capabilities of the human mind. The myth of American Adam, and its valorization of individual reinvention, has been profoundly influential on American politics where fallen figures seem to gain legitimacy through rites of moral confession. As Wilfred McClay (2013: 35) remarks on the fall and rise of President Bill Clinton after the Lewinsky scandal:

"Even after the disgraces of Monicagate and impeachment, and the pardons and disquieting scandals attending Clinton's departure from the White House, and dozens of other embarrassments, his stock remains high. It is not only that he is a quintessential democratic figure. He also has a near-endless native capacity for evoking and receiving the public's redemptive generosity. People tend to forgive him his faults, even if they smile and snicker as they do it."

The Myth of American Adam, thus, is a myth of redemption, premised on core values of individual conversion that feeds the somewhat contradictory assumption that consumption can be both a source of $\sin$ and salvation.

\section{Radical Consumption and the Myth of American Exceptionalism: Fair Trade}

Radical consumption describes a growing category of consumers who, by virtue of the combined influence of Puritan moralism and Transcendental reflexivity, feel anxiety about the ill effects of mass consumption but also see it as a mechanism of positive social change. In this category of consumption, the Puritan ethic and Transcendental insight usefully interact to elevate consumption to the level of a strategic and highly organized social movement.

This category of consumer is perhaps best captured by Jo Littler's recent best seller Radical Consumption: Shopping for Change. Littler (2009: 1-2) describes the expansive scope of this consumptive movement in contemporary society: 
"Ethical consumption, fair trade, consumer protests, brand backlashes, green goods, boycotts and downshifting: these are all now familiar consumer activities - and in some cases are almost mainstream. The specific constellation of anxieties about consumption has combined with the ever-expanding niche markets of neo-liberal consumer capitalism to generate an explosion in sales of 'ethical' goods. Fair trade consumption, for example, has boomed globally, with a 42 percent increase in sales in 2006; in Switzerland, half the bananas bought are now fair trade (Nicholls and Opal 2005: 5; Fairtrade Foundation 2007)...And corporations are now rushing to proclaim their 'ethical' credentials: to show us that they care, and that they are 'socially responsible' (Doane, 2003a, 2003b, 2004; Kotler and Lee 2006; Henriques 2007).”

In contrast to the individual focus of transformative consumption, Radical Consumption marshals the moral indignation of Puritanism with the progressive focus on the future of Transcendentalism to move consumption from care of the self to care of the planet.

The foundation of Radical Consumption in America, according to Daniel Horowitz in his book The Anxieties of Affluence: Critiques of American Consumer Culture, 1939-1979, is good old fashioned moral guilt. In tracing the discursive emergence of this movement, from the consumer activism of Ralph Nader to Naomi Klein, Horowitz (2004: 3) observes a distinct "unexamined and condescending puritanism" and a "politicized moral outrage" whereby Americans develop a growing recognition that their pursuit of the grace of god through secular material success has generated, what economists term, "negative externalities".

Radical Consumption is also based on a thread of Transcendentalist discourse, that focuses on the violation of Thoreau's spiritual exaltation of Nature. From the essays of John Muir to Rachel Carson's highly influential Silent Spring, we can trace an emerging moral outrage to the way in which rationalized industry has destroyed the idealized view of Winthrop's American Eden on Earth and Thoreau's Walden.

The moral guilt that fuels this movement in America can best be understood as a reaction against the Myth of American Exceptionalism. For three centuries, America had transformed Puritan values into a society built on an assumption that those in the New World were the chosen 
people and that America was the celestial manifestation of heaven on earth. The illusion of exceptionalism, however, began to wear during the Vietnam War with the recognition that not only did America exemplify exceptionalism in military prowess, it also lacked moral exceptionalism in politics. America's War on Poverty, initiated during the Johnson administration, was showing little progress, and an emerging energy crisis indicated that the planets supply of oil may actually be finite.

One can trace a thread of the intersection of formal religious and secular spiritual beliefs in the history of the FairTrade consumer movement in the US. Because these movements started after the Great Awakening there is little evidence of direct Puritan or Transcendental engagement in the fair-trade movements, but the tenets of these two foundational doctrines have been taken up by other religious organizations. Quakers (the Religious Society of Friends) were early adopters of a consumer movement to challenge slavery by boycotting goods produced by the plantations. In 1827 Quakers established the "Free Produce Society" by abolitionists like Thomas M'Clintock, who recognized the social and political power of consumption to radically transform the institution of slavery.

More recently, the US based Mennonite Central Committee, with the assistance of Quakers and the Swiss based Church of the Brethern, established SERVV International, one of the first fair trade supply chain organizations, in 1949. The organization emerged as part of an effort to help displaced Europeans in the aftermath of the Second World War and focused on developing markets for handicrafts that were sold in charity stores that used their profits for charitable work. A similar model, also developed by the Mennonite Church, established both the Ten Thousand Villages and Traidcraft supply chains as a moral response to poverty. These movements, based on ideas of liberation theology, served as templates for the now well-known Fairtrade consumer brand. 
The radical element of Fairtrade as a social consumer movement is captured schematically in the brand logo (See Figure 3). The image contains a schema of a defiant individual with arm upraised intended to represent the growing empowerment of the small-holder farmer in the global capitalist market for coffee. As reported in the Fairtrade (FLO 2008: 23) annual report:

"The graphic symbol inside the FAIRTRADE Mark is of a person with a raised arm representing the optimism of producers and linking the everyday determination of people in developing countries with the aspiration of consumers around the world."

Insert Figure 3 about here

The degree to which consumers can actually effect change by consuming FAIRTRADE products is suspect (Brown, 2013). Indeed, the moral outrage of radical consumption and the guilt that motivates them has been empirically demonstrated to be disconnected from behavioral action (Devinney, Auger \& Eckhardt, 2010). However, the assumption that we can re-enchant the world by acts of consumption is so deeply embedded in American consumptive mythology that, as Ritzer (2003) has observed, it is no accident that our sites of consumption - shopping malls - tend to mirror religious cathedrals and mimic natural utopias. Shopping is a social practice that gives comfort, in part, because it reaffirms deep-seated values of predestination and a return to Eden.

\section{Conclusion}

The empirical intent of this essay is to demonstrate the enduring influence of religion and spirituality on contemporary consumption. The theoretical intent is to begin to articulate a philosophy of myth based on collective memory. My core argument is that foundational cosmologies, like formal religions, and their secular extensions, form part of the collective memory of a given social group. Over time, collective memory crystallizes into the ideological morality of myth. Mnemonic communities, be they religious sects or nation states, interpret the empirical 
world, through their prevailing myths. That is, we perceive, think and act, through myths derived from our collective past.

In America, and perhaps in most societies, many prevailing myths emerge from a collective memory of founding religions. Over time, those myths incorporate more secular interpretations. In so doing, however, they create an essential tension, a degree of contradiction that must be obscured or disguised in order to maintain ideological coherence. These tensions, however, become manifest in our political institutions, our knowledge structures and, as I have tried to demonstrate here, in our consumptive behaviors.

As I have shown above, many contemporary brands are premised on appeals to the collective memory of our religious past. These brands appeal by adopting rhetorical strategies that embody our collective history as religious and spiritual creatures. The consumption of these brands, like the consumption of the wafer and wine in the eucharist, provides the consumer with a form of consubstantiation in which he or she, consciously or unconsciously, reaffirms their identification with a common set of foundational beliefs, ideologies and myths embedded in a common rhetorical history (Suddaby, Foster \& Quinn-Trank, 2010). The term consubstantiation has its roots in Catholicism, to describe the union with Christ through the symbolic act of consumption. More recently, however, it was applied by the American rhetorician Kenneth Burke (1969) to refer to the sense of union between rhetor and audience as a result of the rhetors persuasive appeal to common values. I use the term here in both meanings here.

Effective marketers are conscious of the deep causal connections between collective memory, prevailing myths and ideological practices. Like artists and writers, they can tap into deep-seated contradictions embedded in our prevailing myths in order to motivate, inspire and, in some cases, encourage social change. More detailed research is needed. We need to empirically 
isolate social myths and ideologies. We need to understand if these are universal attributes ontological "givens" shared by all - or culturally specific. As this admittedly cursory sketch reveals, we also need to understand the relationship between myths. In the example of Puritan and Transcendental myths we can see a high degree of coherence between the core tenets of asceticism, predestination and conversion and their mythological counterparts. But we know little about the synchronic and diachronic relationships between memory, core tenets and prevailing myths. More practically, we know less about the rhetorical strategies that can be used to mobilize them. 
Table 1: Tenets of Puritanism and Transcendentalism and Defining American Myths

\begin{tabular}{|c|c|c|c|}
\hline Core Values & $\begin{array}{c}\text { Puritan } \\
\text { Expression } \\
\end{array}$ & $\begin{array}{c}\text { Transcendental } \\
\text { Expression }\end{array}$ & Defining Myths of America \\
\hline Asceticism & $\begin{array}{ll}\text { - } & \text { Frugality } \\
\text { - } & \text { Hard Work } \\
\text { - } & \text { Piety }\end{array}$ & $\begin{array}{ll}\text { - } & \text { Introspection } \\
\text { - } & \text { Simplicity }\end{array}$ & $\begin{array}{l}\text { The Myth of the American Dream: } \\
\text { - Material success through hard } \\
\text { work, frugality and piety }\end{array}$ \\
\hline Conversion & $\begin{array}{l}\text { - Regenerative } \\
\text { effect of the } \\
\text { Frontier } \\
\text { - Progress }\end{array}$ & $\begin{array}{ll}\text { - } & \text { Rebirth } \\
\text { - } & \text { Reinventing } \\
\text { the Self } \\
\text { - } & \text { Social } \\
\text { mobility }\end{array}$ & $\begin{array}{l}\text { The Myth of the American Adam: } \\
\text { - Salvation and redemption } \\
\text { through change } \\
\text { - Reinvention of the self in the } \\
\text { New World }\end{array}$ \\
\hline Predestination & $\begin{array}{ll}\text { - } & \text { Promised } \\
& \text { Land } \\
\text { - } & \text { Chosen } \\
& \text { People }\end{array}$ & $\begin{array}{ll}\text { - } & \text { New Eden } \\
\text { - } & \text { Gods on Earth } \\
\text { - } & \text { Nature }\end{array}$ & $\begin{array}{l}\text { The Myth of American } \\
\text { Exceptionalism: } \\
\text { - The Golden City on the Hill }\end{array}$ \\
\hline
\end{tabular}

Table 2: Tenets of Spirituality, American Myths and Social Movements of Consumption

\begin{tabular}{|c|c|c|c|}
\hline Puritan Tenet & $\begin{array}{c}\text { Transcendental } \\
\text { Tenet }\end{array}$ & Defining Myth & $\begin{array}{c}\text { Social Movement of } \\
\text { Consumption }\end{array}$ \\
\hline Asceticism & Self-Reliance & American Dream & $\begin{array}{c}\text { Voluntary Simplicity } \\
\text { (Ikea) }\end{array}$ \\
\hline Conversion & Individualism & American Adam & $\begin{array}{c}\text { Transformational } \\
\text { Consumption } \\
\text { (Lululemon) }\end{array}$ \\
\hline Predestination & $\begin{array}{c}\text { Idealism through } \\
\text { Nature }\end{array}$ & $\begin{array}{c}\text { American } \\
\text { Exceptionalism }\end{array}$ & $\begin{array}{c}\text { Radical Consumption } \\
\text { (Fair Trade) }\end{array}$ \\
\hline
\end{tabular}


Figure 1: IKEA Ad Invoking the Aescetic American Dream

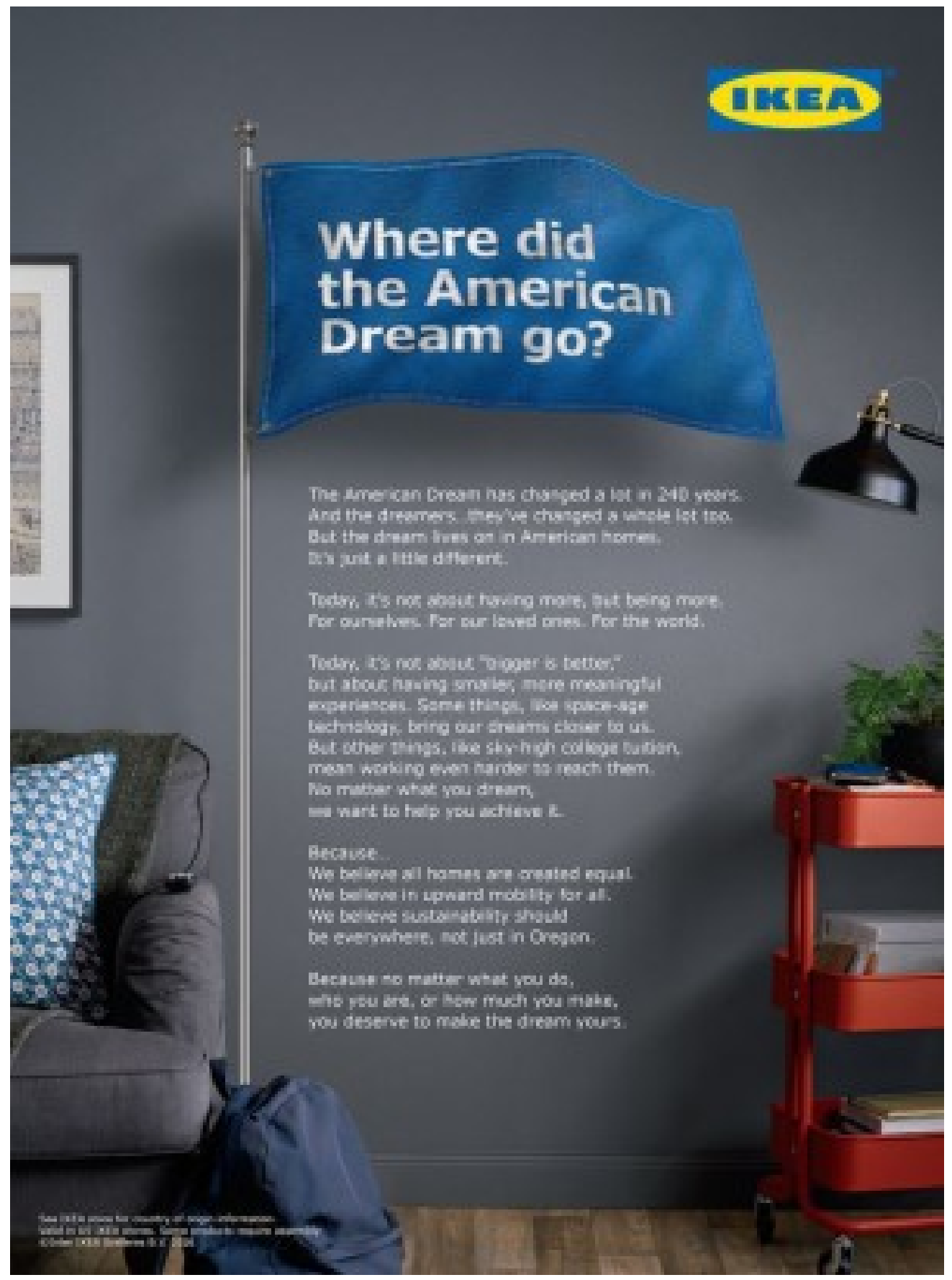


Figure 2: Lululemon Product Bag Invoking the Myth of the American Adam

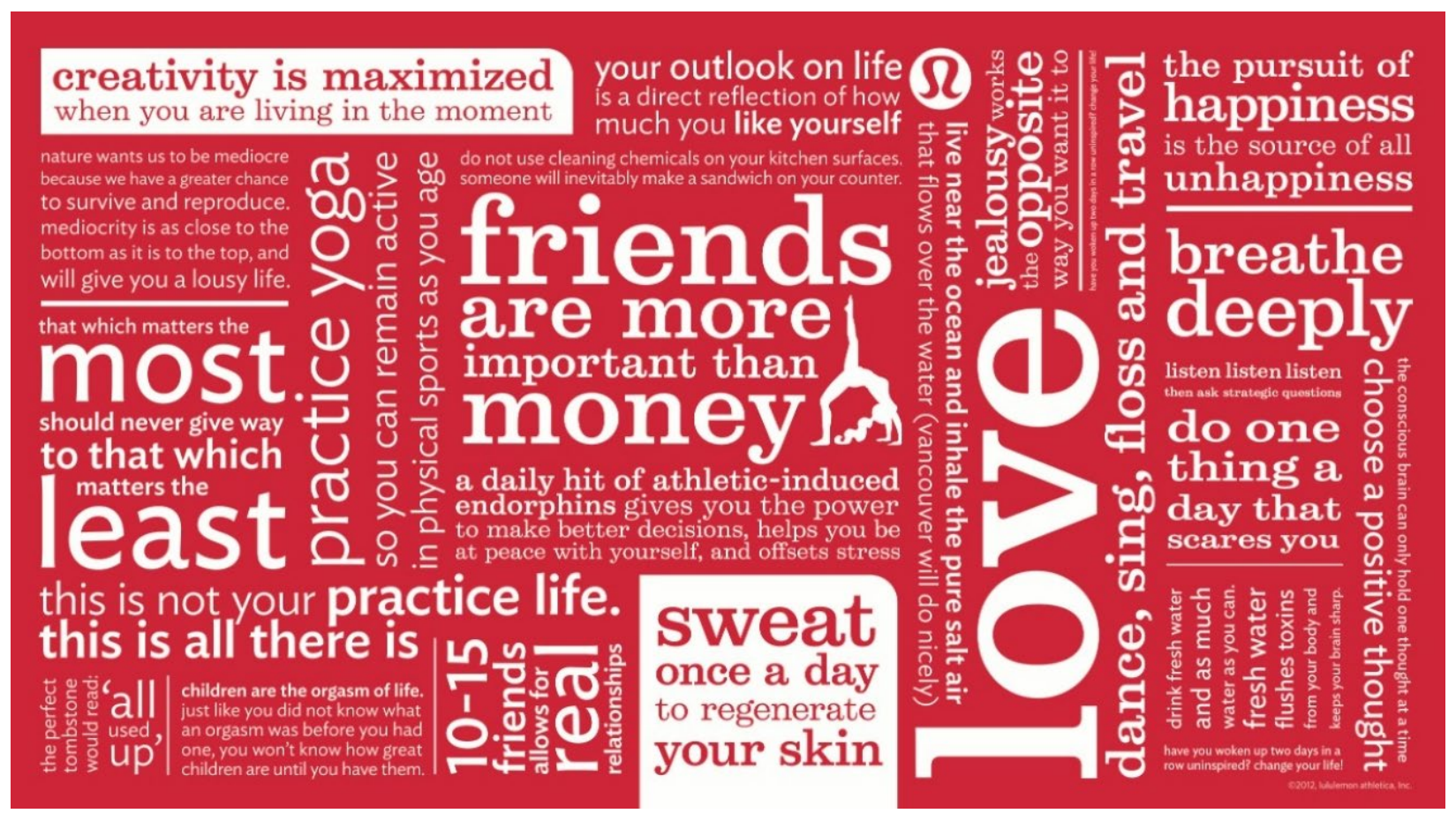


Figure 3: Fairtrade Logo Invoking the Myth of American Exceptionalism

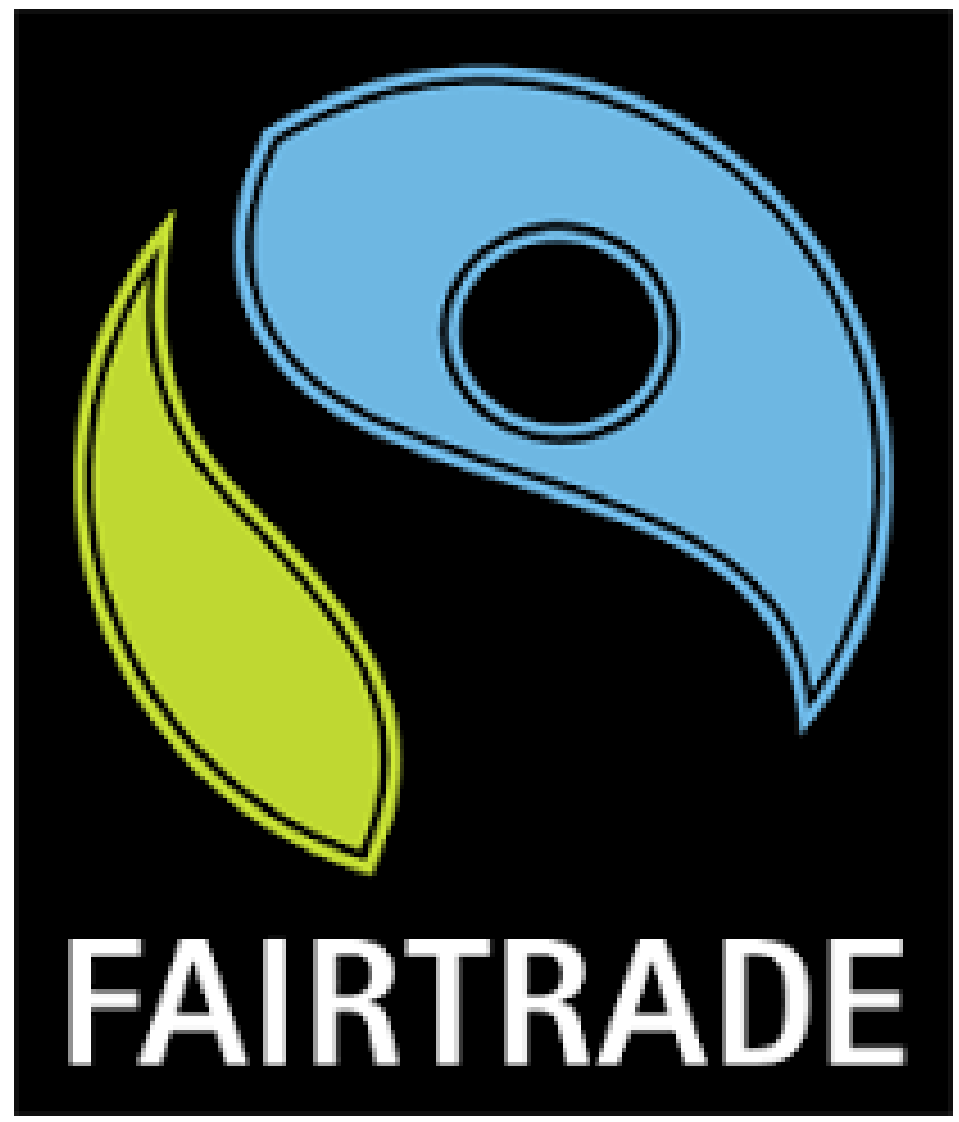




\section{References}

Adams, J.T. 2012 [1931]. The Epic of America. New York: Routledge.

Anderson B. 1991. Imagined Communities. Reflections on the Origin and Spread of Nationalism. New York: Verso. 2nd ed.

Anderson, R.C. 1995. The Great Migration Begins: Immigrants to New England, 16201633. Boston, MA: New England Historical Society.

Assmann, J. 1992. Das Kulturelle Gedachtnis: Schrift, Erinnerung und Politische Identitaet in Fruehen Hochkulturen. Munich, Germany: Beck.

Beir, J. 1972. Weberism, Franklin, and the Transcendental Style. The New England Quarterly, 43 (2): 179-19. 1975.

Bercovitch, S. 1975. The Puritan origins of the American self. Yale University Press,

Brown, K. 2013. Buying into Fair Trade: Culture, morality and consumption. New York: NYU Press.

Burke, K. 1969. A Grammar of Motives. Berkeley, CA: University of California Press.

Cannon, E.F. 2013. The Saloon and the Mission: Addiction, conversion and the politics of redemption in American culture. Amherst, MA: University of Massachusetts Press.

Cova, B., Kozinets, R.V. \& Shankar,A. 2007. Tribes Inc. The new world of tribalism. Pp. 3-26 in Consumer Tribes, Cova, B., Kozinets, R.V \& Shankar, A. eds. Routledge, 2007.

Devinney, T.M., Auger, P. \& Eckhardt, G. 2010. The Myth of the Ethical Consumer. Cambridge, UK: Cambridge University Press.

Diddams, M., Whittington, J.L. \& Divago, T. 2005. Creating in the name of God who creates: A whole life model of spirituality within work. Journal of Management, Spirituality and Religion, 2(3): 310-331.

Eckhardt, G.M., Belk, R.W. \& Wilson, J.A.J. 2015. The rise of inconspicuous consumption. Journal of Marketing Management, 31(7/8): 807-826.

Emerson, E.H. 1977. Puritanism in America, 1620-1750. Ann Arbor, MI: University of Michigan Press.

Emerson, R. W. 1836/2004. Nature. The American Scholar and Self-Reliance. In Essays and poems by Ralph Waldo Emerson New York, NY: Barnes \& Noble. 
Etzioni, A. 1999. Voluntary simplicity: Characterization, select psychological implications, and societal consequences. In Essays in Socio-Economics (pp. 1-26). Springer, Berlin, Heidelberg.

FLO 2008. FLO Annual Report, 2007-2008: About the Mark. Bonn, Germany. Available online. www.fairtrade.net/annual_reports.0.html (accessed July 30, 2008).

Friedman, M. 1970. The social responsibility of business is to increase profits. New York Times Magazine, September 13, 1970.

Gao L, Wheeler SC, Shiv B. 2008. The "shaken self": product choices as a means to restoring self-view confidence. Journal of Consumer Research 36:29-38.

Halbwachs, M. 1992. On collective memory. University of Chicago Press.

Hankins, B. 2004. The Second Great Awakening and the Transcendentalists. Westport, CT: Greenwood Press.

Heimart, A. 1966. Religion and the American mind: From the Great Awakening to the Revolution. Cambridge, MA: Harvard University Press.

Hirschman, E.C. 1988. The ideology of consumption: A structural-syntactical analysis of 'Dallas' and 'Dynasty'. Journal of Consumer Research, 15(3): 344-59.

Holt, D. 2004. How Brands Become Icons: The Principles of Cultural Branding. Boston, MA: Harvard University Press.

Holt, D. B. 2006. Jack Daniel's America: Iconic brands as ideological parasites and proselytizers. Journal of Consumer Culture, 6(3), 355-377.

Holt, D. \& Cameron, D. 2010. Cultural Strategy: Using Innovative Ideologies to Build Breakthrough Brands. Oxford, UK: Oxford University Press.

Horowitz, D. 2004. The Anxieties of Affluence: Critiques of American Consumer Culture, 1939-1979. Amherst, MA: University of Massachusetts Press.

Johnson, E. 1970. Individualism and the Puritan Imagination. American Quarterly, 22(2): 230-237.

Klara, R. 2016. Ikea Says the American Dream Is about More Than Just Buying Stuff. Adweek, September 26, 2016:

Kleine, R.E., Kleine, S.S. \& Brunswick, G.J. 2009. Transformational consumption choices: Building an understanding by integrating social identity and multiple attribute theories. Journal of Consumer Behavior, 8: 54-70. 
Kozinets, R.V. \& Handleman, J.M. 2004. Adversaries of Consumption: Consumer Movements, Activism and Ideology. Journal of Consumer Research, 31: 691- 704.

Lewis, M. 1999. The New, New Thing. New York: W.W. Norton.

Lewis, R.W.B. 1955. The American Adam: Innocence, Tragedy and Tradition in the Nineteenth Century. Chicago: University of Chicago Press.

Littler, J. 2009. Radical Consumption: Shopping for Change in Contemporary Culture. New York, NY: Open University Press.

Luedicke, M.K., Thomson, C.J. \& Giesler, M. 2010. Consumer identity work as moral pragmatism: How myth and ideology animate a brand mediated moral conflict. Journal of Consumer Research, 36: 1016-1032.

Madsen, D. L. (1998). American Exceptionalism. Univ. Press of Mississippi.

Mayo-Santo, R. 2014. Nature Writing, American Exceptionalism, and Philosophical Thoughts in Edward Bliss Emerson's Caribbean Journal, The Qualitative Report, 19: 80-97.

McClay, W.M. 2013. Still the Redeemer Nation. The Wilson Quarterly, 37(2): 20-30.

McKnight, Z. 2013. A rare look at the stretchy and cult-like empire of Lululemon. Vancouver Sun, August 17, 2013. Accessed online at http://o.canada.com/business/a-rare-lookat-the-luon-empire-of-lululemon.

McLoughlin, W.G. 1978. Revivals, Awakening and Reform: An essay on religion and social change in America. Chicago, IL: University of Chicago Press.

Mick DG. 2006. Presidential address: meaning and mattering through transformative consumer research. In: Pechmann C, Price L, editors. Advances in Consumer Research, vol. 33. Duluth, MN: Association for Consumer Research.

Muniz, A. M., \& O'Guinn, T. C. 2001. Brand community. Journal of consumer research, 27(4), 412-432.

Nelson, T. N. 2017. The Transformational Consumer: Fuel a Lifelong Love Affair with Your Customers by Helping Them Get Healthier, Wealthier, and Wiser. Berrett-Koehler Publishers.

Paulson, E.L. \& O’Guinn, T.C. 2018. Marketing social class and ideology in Post-WorldWar-Two American Print Advertising. Journal of Macromarketing, 381): 7-28.

Ritzer, G. 2003. Enchanting a disenchanted world: Revolutionizing the means of consumption. Thousand Oaks, CA: Sage. 
Schembri S, Merrilees B, Kristiansen S. Brand consumption and narrative of the self. Psychol Market 2010;27(6):623-38.

Schroeder, J.E. 2009. The cultural codes of branding. Marketing Theory 9(1): 123-126.

Schroeder, J. E., \& Morling, M. S. 2006. A Cultural Perspectives on Corporate Branding: The Case of LEGO Group. In Brand Culture (pp. 28-44). Routledge.

Schwartzkopf, S. 2012. The market order as metaphysical loot: Theology and the contested legitimacy of consumer capitalism. Organization, 19(3): 281-297.

Shi, D.E. 2007. The Simple Life: Plain living and high thinking in American culture. Athens, GA: University of Georgia Press.

Siegel \& Gale. 2018. Global Brand Simplicity Index, www.simplicityindex.com.

Slotkin, R. 1998. Gunfighter Nation: The myth of the frontier in twentieth century America. Norman, OK: University of Oklahoma Press.

Suddaby, R. 2016. Toward a Historical Consciousness: Following the Historic Turn in Management Thought.M@n@gement,19(1):46-60.

Suddaby, R., Foster, W. \& Quinn-Trank. 2010. Rhetorical History as Competitive Advantage, Advances in Strategic Management, 27: 147-173.

Suddaby, R., Ganzin, M. \& Minkus, A. 2017. Craft, Magic and the Re-enchantment of the World. European Journal of Management. 35(3): 285-296.

Veblen, T. 1927[1899]. The Theory of the Leisure Class: An economic study of institutions. New York: Vanguard.

Whitman, W. 1973. Leaves of grass. In The complete poems of Walt Whitman, ed. S. Bradley and H. Blodgett. New York:Norton. 